\title{
Ichnological record of the Frasnian-Famennian boundary interval: two examples from the Holy Cross Mts (Central Poland)
}

\author{
Michał Stachacz ${ }^{1}$ Alfred Uchman ${ }^{1} \cdot$ Francisco J. Rodríguez-Tovar $^{2}$
}

Received: 2 October 2015 / Accepted: 10 February 2016 / Published online: 2 March 2016

(C) The Author(s) 2016. This article is published with open access at Springerlink.com

\begin{abstract}
The Frasnian-Famennian (Late Devonian) boundary interval within the carbonate-siliciclastic series in the Kowala and Płucki sections (Holy Cross Mts, Central Poland) has been analysed to evaluate the influence of the Kellwasser event on the macrobenthic tracemaker community. The Upper Kellwasser event has a lithologically variable record, as horizons of flints (Kowala) and as a bed of bituminous, black, cephalopod limestone (Płucki). Both sections show mostly laminated, unbioturbated beds of marlstones or shales just above the Frasnian-Famennian boundary, which point to events of anoxia on the sea floor. However, the first anoxic horizon occurs below the Frasnian-Famennian boundary. The trace fossils and bioturbational structures are uncommon and poorly diversified. Trichichnus and Multina are the only frequent trace fossils in some beds. Moreover, one horizon above the FrasnianFamennian boundary contains numerous Multina and a single ?Planolites. Such poorly diversified trace fossil assemblage suggests an unfavourable environment for most of burrowing organisms and fluctuations in oxygenation from anoxic, to dysoxic conditions. The occurrence of the trace fossils and bioturbational structures as spotted and mottled ichnofabrics from the $1.3 \mathrm{~m}$ above the Frasnian-Famennian
\end{abstract}

Michał Stachacz

michal.stachacz@uj.edu.pl

Alfred Uchman

alfred.uchman@uj.edu.pl

Francisco J. Rodríguez-Tovar

fjrtovar@ugr.es

1 Institute of Geological Sciences, Jagiellonian University, Oleandry 2a, 30-063 Kraków, Poland

2 Department of Stratigraphy and Palaeontology, Sciences Faculty, University of Granada, Granada, Spain boundary is interpreted as an improvement in bottom water oxygen conditions after the Upper Kellwasser event.

Keywords Trace fossils · Frasnian-Famennian · Devonian · Kellwasser event $\cdot$ Trichichnus $\cdot$ Multina . Poland

\section{Introduction}

One of the larger mass extinctions in Earth history happened during the Frasnian-Famennian (F-F; Late Devonian) transition. It concerned mostly shallow-water organisms living in warmer environments, foremost reef-builders (Rugosa and Tabulata cap corals, stromatoporoids) as well ammonoids, tentaculites, conodonts, placoderms and brachiopods (e.g. Hallam and Wignall 1997; McGhee 2013). The Late Devonian extinction has been recently interpreted as a "biodiversity crisis" caused by speciation rate collapse rather than a classic "mass extinction" (e.g. Racki 2005; Becker et al. 2012; Gereke and Schindler 2012). This crisis is related mostly to sea level changes (e.g. Hallam and Wignall 1999; Stigall 2012) or climate variations (Joachimski et al. 2009); however, the main reasons are still unclear. In Europe, the F-F extinction event is recorded usually as a series of black limestones called the Kellwasser, which are associated with anoxia (e.g. Buggisch 1991; Joachimski et al. 2001; Marynowski et al. 2011). Relationships between anoxia, sea level changes and the F-F mass extinction were proposed from the cited papers, but they are not universally accepted (see detailed review in Bond and Wignall 2008); it seems that the extinction has a more multicausal nature (Racki 2005; Gereke and Schindler 2012). In the latest years, important Mesozoic and Cenozoic anoxic events have been studied by means of the 
ichnological approach, as those occurring at the Toarcian Oceanic Anoxic Event (T-OAE; Rodríguez-Tovar and Uchman 2010; Rodríguez-Tovar and Reolid 2013; Reolid et al. 2014), the Cenomanian-Turonian boundary (Uchman et al. 2008, 2013a, b; Rodríguez-Tovar et al. 2009a, b; Monaco et al. 2012), or the Oligocene-Miocene (Kotlarczyk and Uchman 2012). Much less is known about ichnology of the F-F transition. Buggisch (1991) only mentioned the laminated, unbioturbated deposits on the F-F boundary. Bond et al. (2004) reported bioturbated sediments, "microburrows" and "larger, wispy burrows" in the Famennian of the Kowala section in the Holy Cross Mountains in Poland (studied in this paper). Wang et al. (2006) presented an assemblage of trace fossil as a record of recovery through the Famennian in South China. Haddad et al. (2013) and Boyer et al. (2014) focused on ichnology and geochemistry of the boundary interval in the USA. The latter authors described a trace fossil assemblage dominated by deep-tier, pyritized Skolithos and Chondrites, beside as less abundant Thalassinoides close to the Upper Kellwasser interval. Stachacz and Uchman (2012) presented preliminary results of ichnological studies of the F-F interval of the Holy Cross Mountains in Poland, which are developed in this paper.

The Holy Cross Mountains in Central Poland offer two important sections of the Frasnian-Famennian transition at Kowala and Płucki (Fig. 1), where black, anoxic sediments, referred to the Upper Kellwasser, crop out. They are the target of a "bed-by-bed" ichnological analysis, from which the results and discussion are presented in this paper.
Earlier geochemical studies of the Kowala section show general oxygen deficiency near the sea floor during the F-F transition (Joachimski et al. 2001; Bond et al. 2004). More complex oxygenation changes are referred to the high total organic carbon (TOC) content at the F-F boundary interval, which is interpreted as a result of a higher input of organic matter (Racki et al. 2002).

\section{Geological setting}

\section{General remarks}

The study area is located in the southern part of the Holy Cross Mountains called the Kielce Region (Fig. 1), which is a surface part of the Małopolska Block (e.g. Buła 2000; Cocks and Torsvik 2005). Late Devonian sedimentation took place here on an extensive shelf in the marginal part of the Laurussia palaeocontinent (e.g. Joachimski et al. 2001; Racki et al. 2002; Marynowski et al. 2011 and references cited therein). The Kowala section is in an active large quarry located south of Kielce, while the Płucki section is available in a small, abandoned quarry located north-west of Płucki (Figs. 1, 2).

The Upper-Middle Devonian (Frasnian) in the Kielce Region of the Holy Cross Mountains is developed as a series of shallow water, stromatoporoid-coral reef limestones (Dyminy Reef), which are 330-800 m thick (Narkiewicz et al. 1990). The reefs rimmed the northern margin of the carbonate shelf of the Małopolska Block and formed a

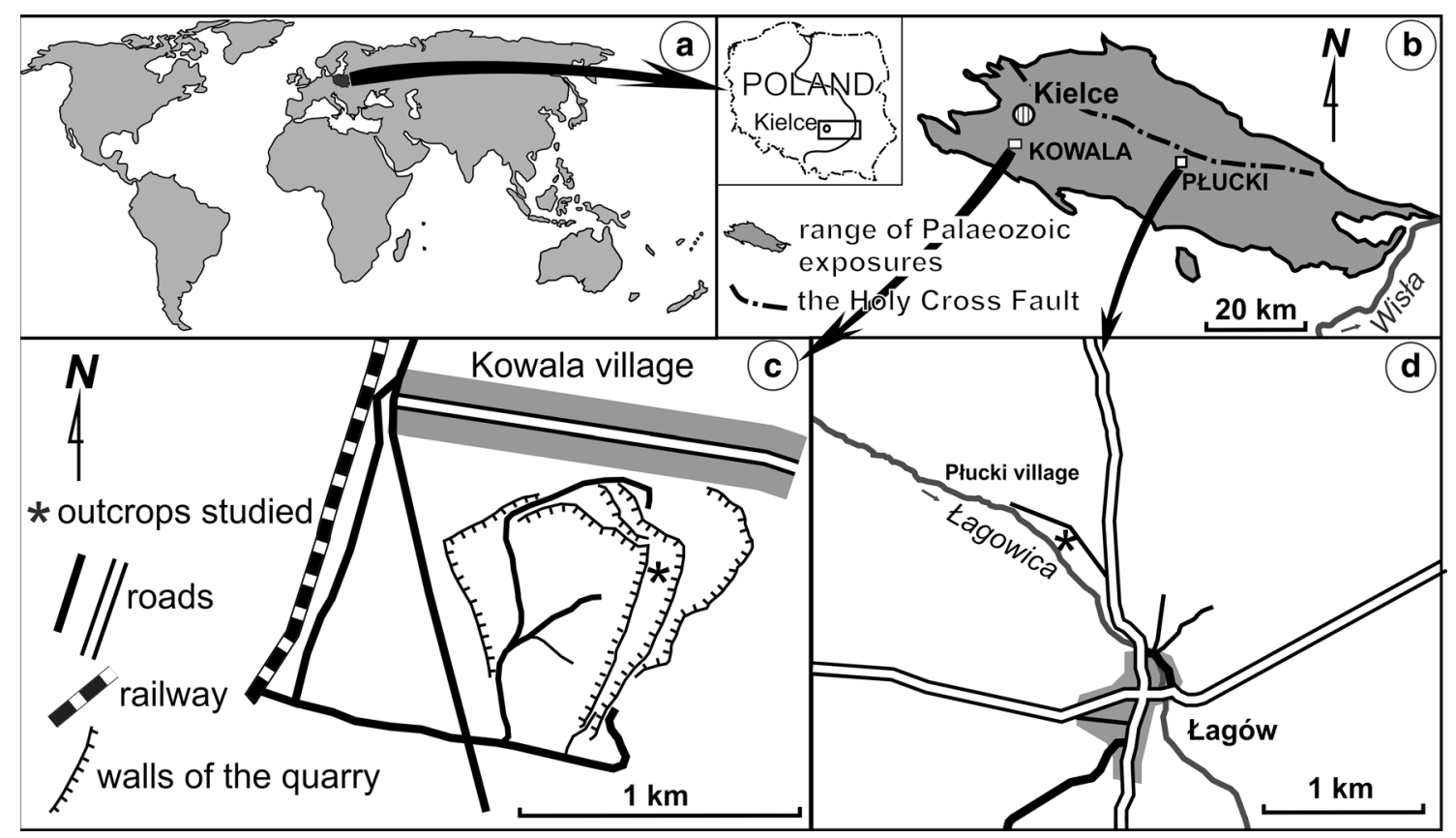

Fig. 1 Locality maps. a, b General location. c Sketch draw of the Kowala quarry. d Location of the Płucki exposure near Łagów 
distinct positive relief in this part of the basin, while the Łysogóry Basin located to the north was much deeper (Narkiewicz 1988). Generally, the Late Devonian reefs stretched along the southern margin of Laurussia (e.g. Copper 2002). The reefs were almost totally flooded at the end of Frasnian (Racki 1990). As a result, they are capped by pelagic limestones, marlstones and shales of the Famennian, which are interpreted as turbidite fed from eroded parts of the carbonate platform located between the southern Chęciny-Zbrza Basin and the Łysogóry Basin to the north (Joachimski et al. 2001). The F-F boundary interval usually occurs in this area as a thick series of limestones interbedded by marlstones, marly or silty shales (e.g. Joachimski et al. 2001; Racki et al. 2002; De Vleeschouwer et al. 2013 and references cited therein). The so-called Lower Kellwasser and Upper Kellwasser can be distinguished within such lithology in the Płucki section, while in the Kowala quarry section these horizons are difficult to recognize (cf. Racki et al. 2002). The boundary interval in the Kowala quarry mainly consists of grainstones and micritic limestones which contain two or three layers of nodular cherts (Joachimski et al. 2001; Figs. 5, 6). Geochemical records from this locality, especially TOC, show two maxima that could be related to the two Kellwasser episodes (Joachimski et al. 2001). According to the cited authors, the stratigraphically lower TOC maximum corresponds with the Lower Kellwasser horizon, while the basal part of the upper TOC maximum coincides with the Upper Kellwasser horizon. The upper part of the upper TOC maximum is about $8 \mathrm{~m}$ above the F-F boundary, within the H-3 unit (Joachimski et al. 2001). In the same Kowala section, Racki and Baliński (1998) and Racki et al. (2002) noted benthic biota extinction and biotic switch from mostly calcareous benthos and plankton to silicisponges and radiolarians at the transition from the unit $\mathrm{H}-2$ to the unit $\mathrm{H}-3$, just below the F-F boundary. According to Filipiak (2002), there are no important changes in assemblages of marine palynoflora below and above the F-F boundary; however, more diverse palynofacies around this boundary may be a result of eutrophication. The Upper Kellwasser horizon corresponding to the F-F boundary crops out in the Plucki section, where it was examined for this study (Fig. 2). The section
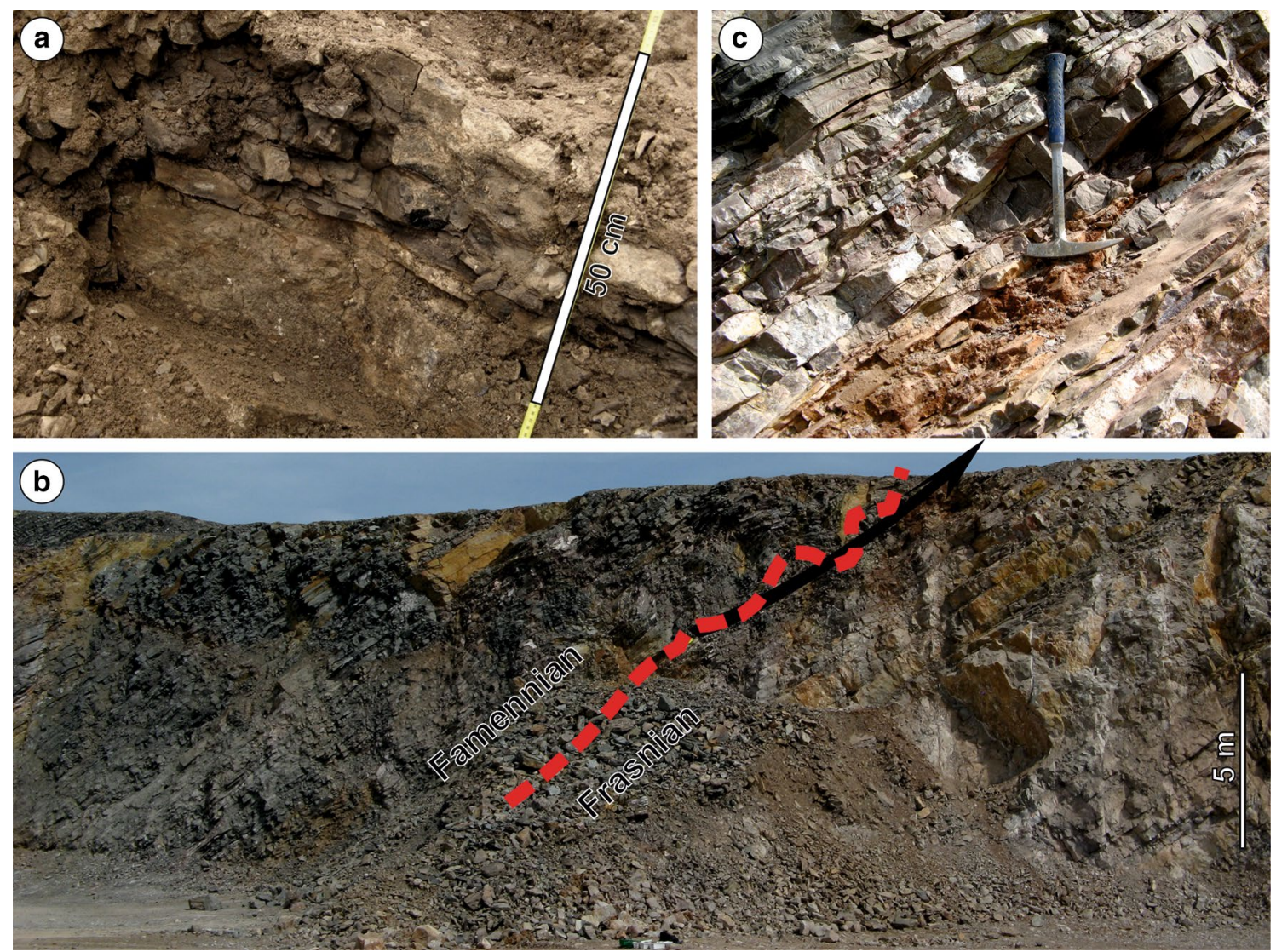

Fig. 2 Outcrops studied. a Upper Kellwasser cephalopod limestone bed in the Płucki section. b, c Frasnian-Famennian transition interval, north-east wall of the Kowala quarry; b General view of wall, talus limestones are visible on the right, F-F boundary interval rep- resented by micritic limestones with horizons of flints in central part, and Famennian micritic and nodular limestones and marls on the left; c Micritic, laminated limestones with one of the flint horizon of the $\mathrm{F}-\mathrm{F}$ boundary interval. The hammer is $40 \mathrm{~cm}$ long 
is composed of micritic limestones and marls, in which the F-F boundary is recognized within a medium bed of cephalopod limestone (Racki et al. 2002; Szrek and Ginter 2007). A distinct benthic fauna crisis was documented in this section by Racki and Baliński (1998) and Olempska (2002).

\section{Outcrops studied}

\section{Ptucki outcrop}

In a small pit, $1 \mathrm{~km} \mathrm{NW}$ of Łagów (Fig. 1), an approximately 5-m-thick section of carbonate-siliciclastic rocks is exposed (Fig. 3). The lower part of the section, about $1.5 \mathrm{~m}$ thick, mostly consists of marlstones interbedded with rare beds of silty shale. Primary horizontal lamination is dominant both in marlstones and in silty shales; however, some marlstone beds are slightly bioturbated, showing spotted and less commonly mottled fabrics and then partly disturbed laminations. The bioturbational structures are usually tiny, up to $3 \mathrm{~mm}$. A large number of beds in this part of the section contain the trace fossil Trichichnus isp., which is visible in cross section as numerous minute ferruginous spots with a halo (Fig. 6). The upper part of the section is composed mostly of laminated or massive, micritic limestones and less commonly slightly bioturbated limestones. The base of this part contains two beds of corroded limestones: the higher one represents the Upper Kellwasser horizon (Janiszewska et al. 2007; Szrek and Ginter 2007). This bed contains numerous poorly preserved goniatites, clymenids, nautiloids, brachiopods and rare trilobites. Racki et al. (2002) distinguished a pure limestone unit (Unit C) which includes strongly bituminous cephalopod limestone layer at the bottom part, followed by a thin coquina intercalation, and then rhythmically bedded, unfossiliferous marly limestones and shales with brachiopods at the topmost part. Moreover, Bond et al. (2004) recognized the bivalve aff. Buchiola sp., entomozoacean ostracoda and homoctenids. Only some beds of limestones contain Trichichnus isp. The beds above and below the Upper Kellwasser horizon are usually also partly corroded and contain numerous corroded clasts and nodules (Fig. 6d). The limestone beds are rarely interbedded with thin beds of silty shales (Fig. 4). One specimen of the trace fossil ?Curvolithus isp. has been found about $60 \mathrm{~cm}$ under the F-F boundary (Fig. 7f).

\section{Kowala quarry}

This is an active quarry is located $5 \mathrm{~km} \mathrm{SW}$ of Kielce (Fig. 1). The Frasnian-Famennian boundary interval is cropped out on the north-eastern wall of the quarry, on the two lowermost exploitation levels (Fig. 2), where lateral changes in lithology have been observed during the study in the years 2011, 2012 and 2015 (cf. Racki et al. 2002). The lower part of the interval is composed of talus rudstone beds containing mostly fragments of stromatoporoids and Rugosa corals. In previous studies of this lower part, a mostly rhythmic, marly succession was subdivided into the H1 and H2 units (Racki et al. 2002; Vishnevskaya et al. 2002) or the units 4 and 5 (Bond et al. 2004). These units were recognized-May 2012 and September 2015, which are recently represented by thick beds of bioclastic limestones. This is explained by the lateral facies changes which are exposed by the progress in exploitation and removal of the previously observed rocks within the active, large quarry. Above the lower part, an approximately 1-m-thick series of laminated, in places "spotted," limestones, which contain abundant Trichichnus isp. and other, sparse non-identified bioturbational structures (Figs. 4, 7,8 ), is observed. The limestones, in the interval located 150-260 $\mathrm{cm}$ above the rudstones, contain three beds of micritic limestones with a 3 or 4 horizons of flints (Fig. 5). The third bed contains two flint horizons (Fig. 6d), where according to bibliographical data in previous studies (e.g. Joachimski et al. 2001), the Frasnian-Famennian is recognized. Above this bed, laminated, non-bioturbated beds of limestones and marlstones crop out. A characteristic, laminated bed of marlstone with corroded, bioturbated nodules and pyrite concretions and impregnation occur about $50 \mathrm{~cm}$ above the F-F boundary. A metre above the boundary, beds of marlstones display primary lamination, partly disturbed by unidentified bioturbational structures (Fig. 6g). Higher up (few decimetres to $1.7 \mathrm{~m}$ ), bioturbated marlstones and limestones contain numerous trace fossils-small Multina isp. and ?Planolites (Figs. 6h, $7 \mathrm{~g}-1$ ). Fluctuating content of carbonates and strong lateral lithological changes are characteristic features of this part of the section. A few horizons, especially $0.5-1 \mathrm{~m}$ above the F-F boundary, show numerous corroded carbonate clasts and nodules within shales, marlstones or silty shale, which are laterally partly replaced by dissolved limestone.

\section{Trace fossils assemblages and bioturbational structures}

Both, the Kowala and Płucki sections show numerous beds which contain abundant Trichichnus isp., characteristically in the uppermost part of the Frasnian (Figs. 3, 4, 5, 6, 7, 8). The largest number of Trichichnus isp. occurs in laminated limestones usually without other trace fossils or bioturbational structures (Figs. 6b, 7a-e, 8). Trichichnus is visible as reddish or brownish, ferruginous or pyritized threads and spots. They are generally isolated, $0.5-1.2 \mathrm{~mm}$ in diameter, in the Plucki section with distinct brighter halo, which is up to $5 \mathrm{~mm}$ in diameter. The outer margin of the halo is 


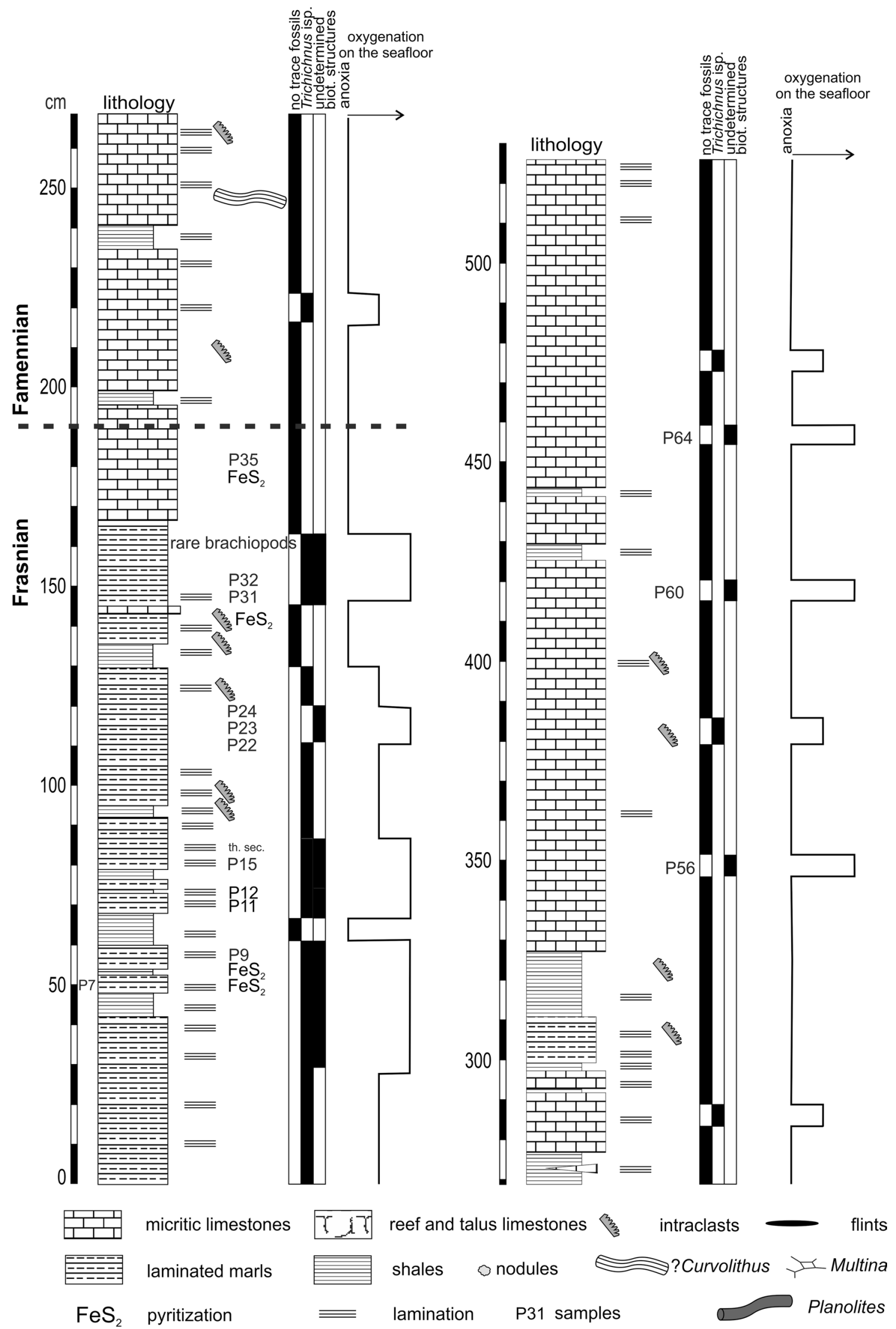

Fig. 3 Log of the Frasnian-Famennian boundary interval with Kellwasser bed in the Plucki section. The curves of the oxygenation on the sea floor based on presence or absence of the trace fossils and bioturbation structures, not to scale 

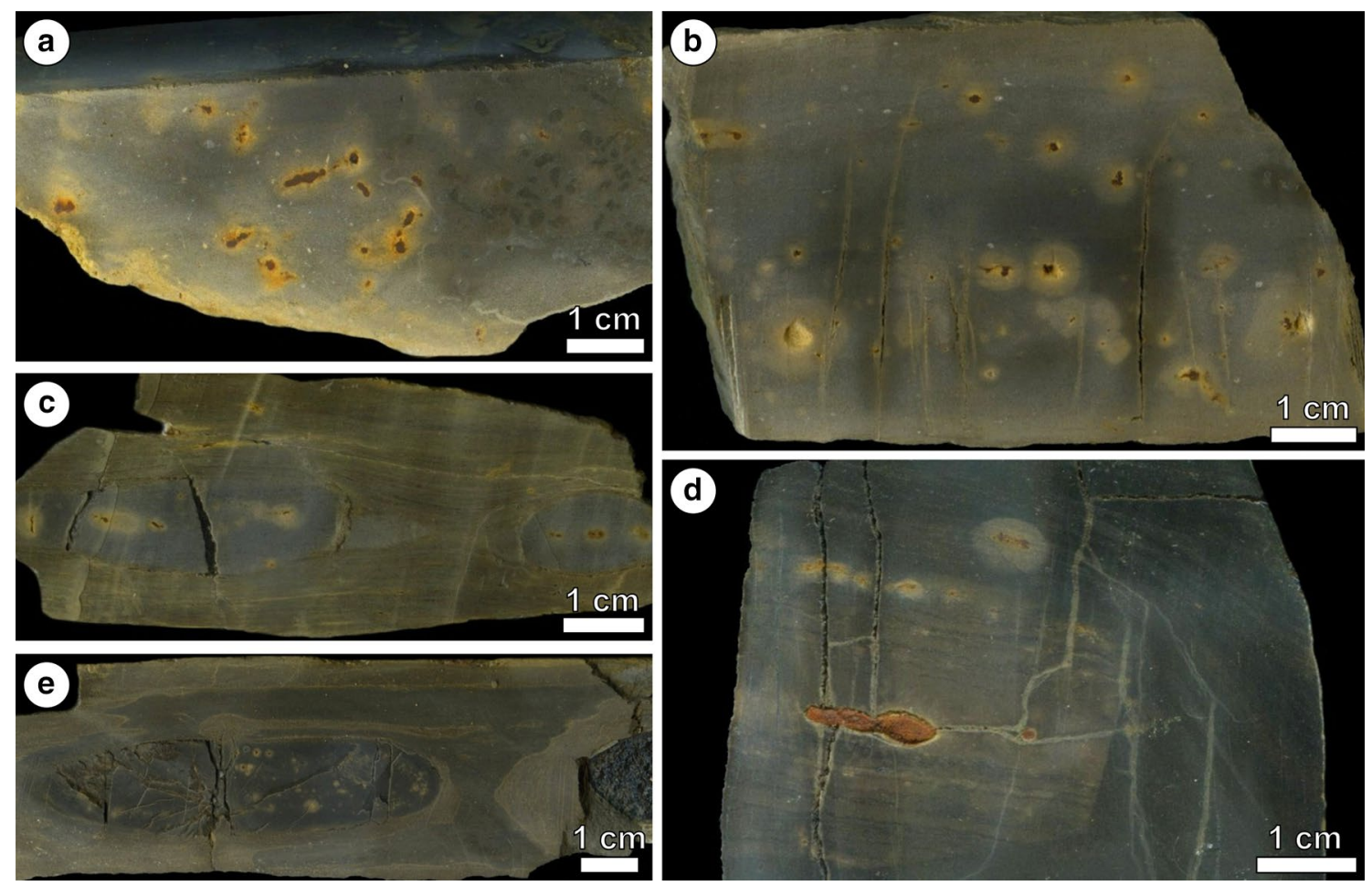

Fig. 4 Sedimentary structures and trace fossils, Płucki section. a, b Trichichnus isp. in micritic limestone; a Horizontal cut; b Vertical cut; c-e partly corroded nodules of limestone contain specimens of Trichichnus isp. within laminated marls; vertical cuts

diffusive. Determination of the length of Trichichnus visible in surfaces of cut slabs is difficult; the longest observed fragment attains a length of about $20 \mathrm{~mm}$. Other trace fossils are generally absent or their state of preservation does not permit a closer determination; however, some of them can be reservedly assigned to Multina isp. and ?Planolites isp. (Fig. $7 \mathrm{~g}-1$ ). Both mentioned trace fossils are visible only in fractured or polished surfaces. Multina in cross section is visible as spots and short, branched and unbranched stripes. Series of cuts allow an insight in their 3-D morphology. They are endichnial, horizontal, oblique and vertical thin, tubular, branched strings, which are unlined, about $0.3 \mathrm{~mm}$ in diameter and filled with material of different colours than the host rock. The branched strings form irregular polygons, which show many crossings at different levels that formed a 3-D network (Fig. 7g-1). Specimens of ?Planolites isp. are visible as subcylindrical rollers of $0.4 \mathrm{~mm}$ in diameter (Fig. $7 \mathrm{k}-1$ ). Only one specimen of ?Curvolithus isp. from the Plucki section is visible as an epichnial ribbon, about $40 \mathrm{~mm}$ wide, with a distinct bevel on the one side (Fig. 7f). Its state of preservation does not permit a closer determination. Clearly visible but undetermined bioturbational structures occur only within a very few beds. They are represented by irregular, straight or slightly curved stripes up to $5 \mathrm{~mm}$ long on the cut surfaces (Fig. 6g). However, most of the slightly bioturbated beds show only indistinct spotted or mottled ichnofabric (Fig. 6c, g, h).

\section{Discussion}

\section{Trace fossil assemblage at the Frasnian-Famennian transition in Central Poland}

Comparative analysis of the Frasnian-Famennian boundary interval in the studied sections at the Kowala Quarry and the Płucki outcrop shows similar features, such as variable carbonate content, lateral lithological changes and the presence of horizons with the abundant ferruginous or pyritized trace fossil Trichichnus isp. However, detailed ichnological analysis through the F-F transition reveals significant differences, which are as follows:

1. in the Upper Frasnian of the Kowala section, below the F-F boundary, numerous laminated, unbioturbated, limestone beds are punctuated only by the presence of several intervals with abundant Trichichnus, while the Płucki section is dominated by bioturbated beds (frequent Trichichnus and rare, undetermined bioturbational structures), with a few unbioturbated intervals;

2. at the F-F boundary, similar ichnological features are present in both sections, generally manifested by the 


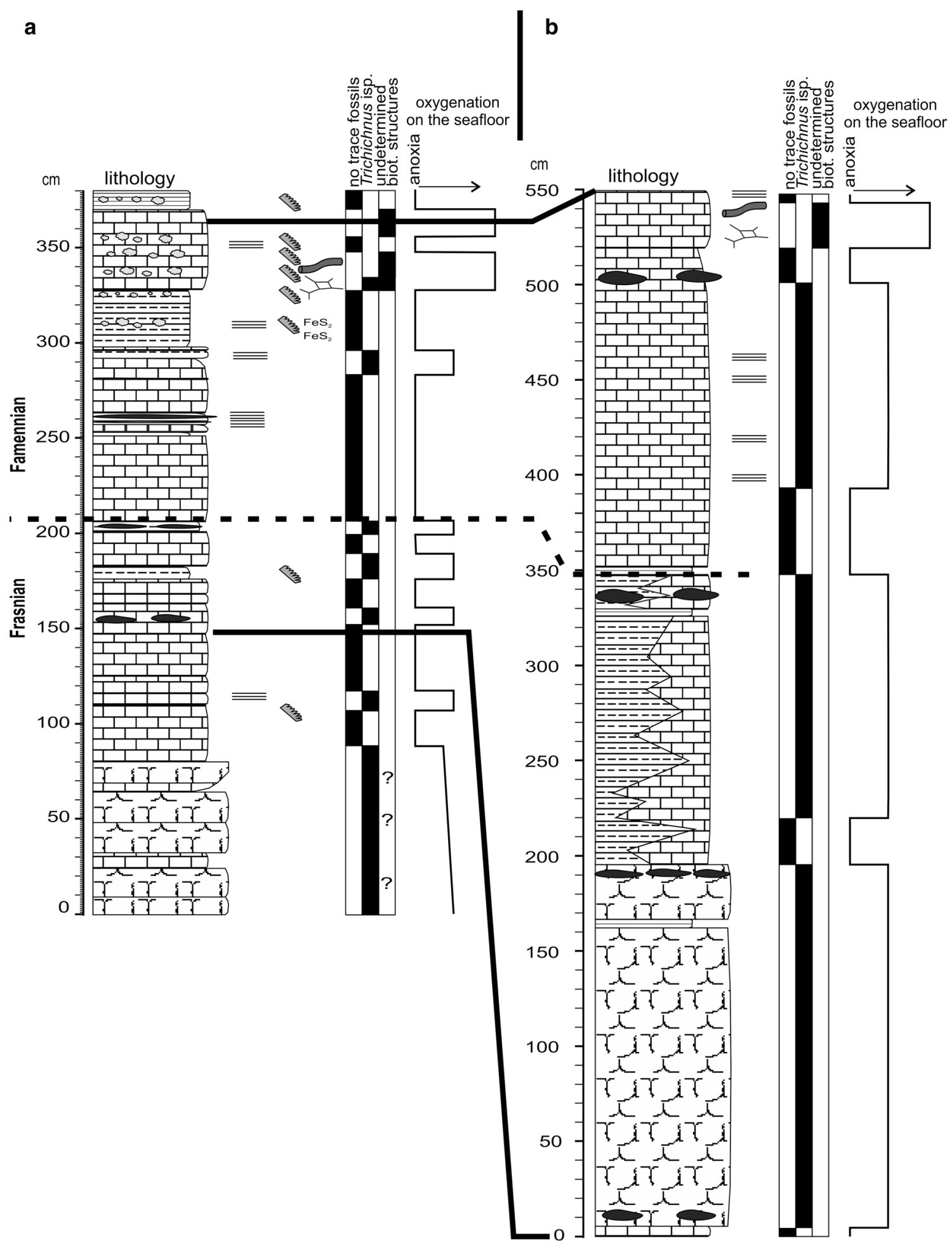

Fig. 5 Log of the Frasnian-Famennian boundary interval in the Kowala quarry. The curves of the oxygenation on the sea floor based on ichnological data, not to scale. a Data from the years 2011-2012 and b data from the year 2015

disappearance of trace fossils. However, this absence is registered several centimetres below the boundary in the Kowala section, and just below the F-F boundary in the Płucki section;
3. above the F-F boundary, trace fossil assemblages are significantly different between the sections, with the appearance of larger structures (Multina and ?Planolites), some centimetres above the F-F boundary in the 

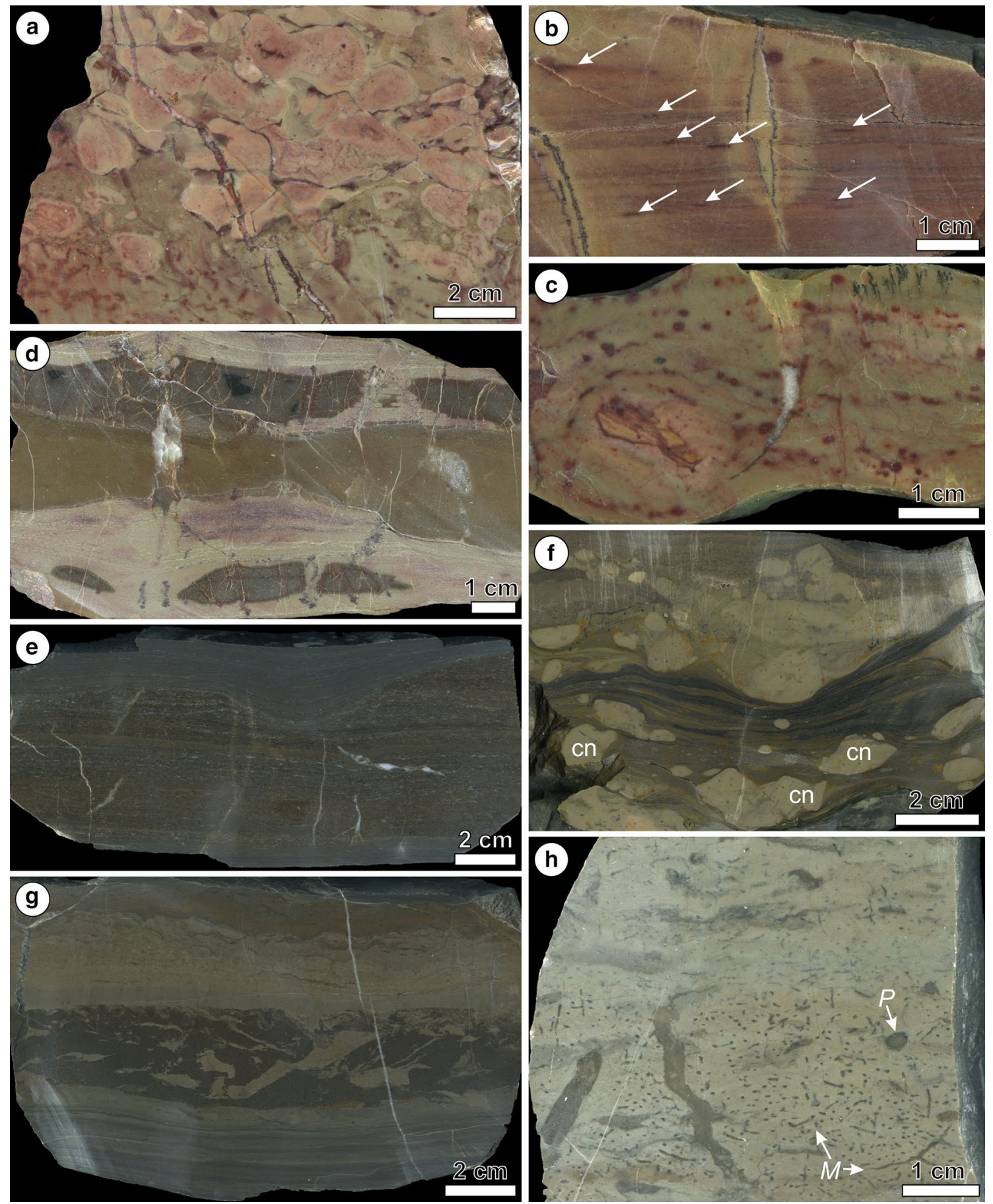

Fig. 6 Sedimentary structures, diagenetic structures and trace fossils in polished surfaces, Kowala quarry. a Bed of talus rudstones. b Laminated beds of limestones with Trichichnus isp. white arrows. c Mixed layer contain numerous Trichichnus isp. d Frasnian-Famennian boundary, bed of laminated limestone with two horizons of flint.

Kowala section, while unbioturbated beds with only rare record of Trichichnus, ?Curvolithus or undetermined bioturbational structures are present in a thick interval above the boundary in the Plucki section. e Bed of laminated marl. f Partly laminated bed of marl with corroded, bioturbated nodules (cn) and pyrite. $\mathbf{g}$ Bed of laminated, partly bioturbated marl. $\mathbf{h}$ Bed of bioturbated limestone that contains mainly Multina isp. $(M)$ and ?Planolites isp. $(P)$

The significant differences in composition and distribution of trace fossils and bioturbational structures in the F-F boundary intervals of the two studied sections could be related to a different incidence of the Upper Kellwasser 

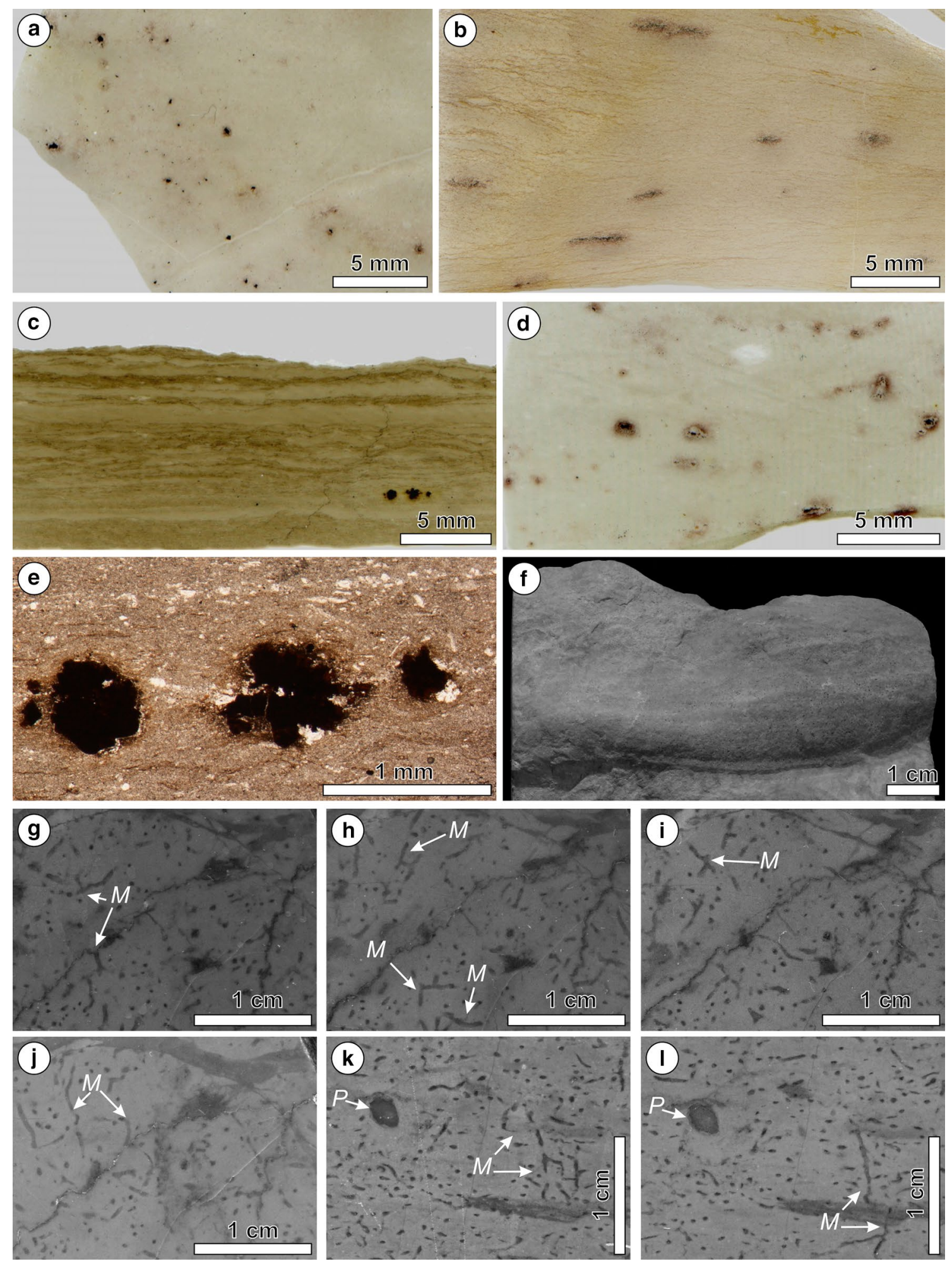

Fig. 7 Trace fossils from the F-F boundary interval of Kowala and Płucki sections. a-e Trichichnus isp. in thin sections; a horizontal cut; b-f vertical cut; a, b, d Kowala; c, e Płucki. f ?Curvolithus isp., epichnion on medium bed of marls. g-l Multina $(M)$ and Planolites $(P)$ in sections, Kowala; $\mathbf{g}-\mathbf{j}$ vertical cut; $\mathbf{k}, \mathbf{l}$ horizontal sections; distances between neighbouring cut ca. $0.3 \mathrm{~mm}$ 


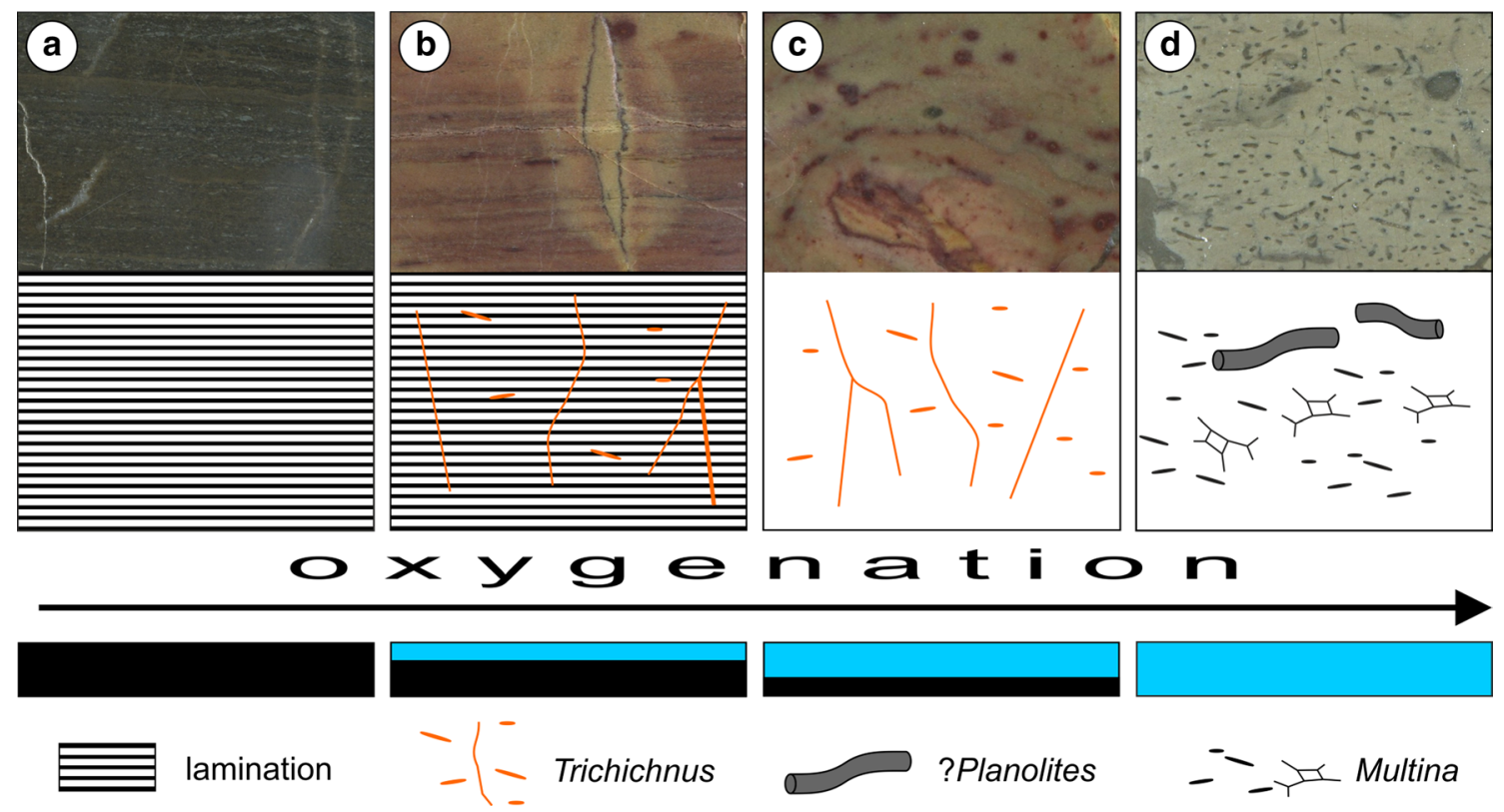

Fig. 8 Sketch draw and examples of the record of deposit oxygenation. a Laminated, non-bioturbated deposit, b laminated deposit with Trichichnus isp., c mixed layer with Trichichnus isp., d bioturbated,

event in the regional depositional setting. The Devonian sediments of the Holy Cross Mountains were deposited in a 600-km-wide shelf, showing palaeogeographic and topographic variations. The Kowala section corresponds to a shallower, intrashelf depositional setting (Chęciny-Zbrza Basin) near the Dyminy Reef, while sediments of the Płucki section were deposited in the deeper Łysogóry Basin (e.g. Racki et al. 2002). These different depositional settings could determine a variable incidence of the palaeoenvironmental changes affecting macrobenthic tracemaker community prior, during and after the Upper Kellwasser phenomena, and thus the different ichnological record. Thus, in the Kowala setting deterioration of the macrobenthic tracemaker environment took place earlier (prior to the Upper Kellwasser event), but also the recovery was comparatively earlier after the event, while in the Phucki section, the ichnological data point to a depauperated environment that appeared nearly simultaneously with the Upper Kellwasser event and persisted for longer after the event.

\section{Oxygenation/productivity changes at the Upper Kellwasser event}

Previous integrative analyses of the Frasnian-Famennian boundary interval in the Holy Cross Mountains mainly focused at the Kowala section, referred to changes in oxygenation and productivity as the main environmental factors during the Upper Kellwasser event (e.g. Joachimski et al. 2001; Girard and Lécuyer 2002; Pujol et al. 2006; spotted layer with Multina isp. and Planolites isp. The improvement of oxygenation follows the recovery trend after the F-F mass extinction, interpreted by Wang et al. (2006)

Borcuch and Rakociński 2007). The analysis of V/Cr ratios, with values of 0 about $2.5 \mathrm{~m}$ below the F-F boundary, 6 at the F-F boundary, and 18 about $8 \mathrm{~m}$ above this boundary (Joachimski et al. 2001), clearly points to anoxia after this boundary. The $\mathrm{V} / \mathrm{Cr}$ ratios $>5$ in a few spots below the F-F boundary point anoxia also before this crisis. However, a later study shows different values of $\mathrm{V} / \mathrm{Cr}$ ratios ( 0.25 at the F-F boundary and 2.25 tens of centimetres above the boundary) and suggests general dysoxia and the absence of a permanent anoxia at the F-F boundary transition (Racki et al. 2002). The lowering in oxygenation just above the F-F boundary in the Kowala section is indicated by the Ce anomaly (Girard and Lécuyer 2002). However, the anoxia during the Kellwasser episodes was intermittent, perhaps seasonal, not permanent (Racki et al. 2002 and cited references therein). A cyclic model of anoxicdysoxic-weakly oxic conditions during the Late Devonian accompanied by mass occurrences of cyanobacterial mats which colonized the oxygen-deficient sea floor was proposed by Kaźmierczak et al. (2012). Similar, anoxicsuboxic-oxic environments based on pyrite framboid size and cyanobacterial mats on the sea floor around the F-F boundary at Kowala were interpreted by Marynowski et al. (2011). Complete absence of bioturbational structures in the Lower and Upper Kellwasser beds in Germany suggest anoxia (Buggisch 1991). Ichnological data obtained in the present study generally agree with the interpretations by Buggisch (1991) and Joachimski et al. (2001), but they bring a more precise picture of the oxygenation changes. 
Trichichnus, probably produced by opportunistic chemosymbionts (Uchman 1995), is typical of poorly oxygenated deposit (McBride and Picard 1991), especially if it occurs as the only trace fossil (Kotlarczyk and Uchman 2012). Recently, Kędzierski et al. (2015) proposed that the ichnogenus Trichichnus is a structure of fossil bioelectric bacterial activity at the oxic-anoxic interface in the sea floor. The disappearance of brachiopods (Racki and Baliński 1998), and benthic ostracods (Olempska 2002) about the F-F boundary, confirms oxygen deficiency. However, other causes, such as a drastic decrease in temperature, which is evidenced by $\delta^{18} \mathrm{O}$, have been also invoked (Joachimski and Buggisch 2007).

The above-presented variations in composition and distribution of trace fossils, bioturbational structures and laminated intervals could be associated with fluctuations in oxygen conditions from anoxic (laminated) to strongly dysoxic (horizons with Trichichnus) and dysoxic (spotty and mottled ichnofabrics, with Multina and ?Planolites). The presence of stromatoporoids and corals point to good oxygenation during the Frasnian. In detail, the interpretation is as follows:

1. below the F-F boundary, the Kowala section shows V/ $\mathrm{Cr}$ values close to 0 reflecting oxic conditions and then numerous, minor, changes (values of $0-0.8$ ) associated with fluctuations between oxic and anoxic conditions close, from around $100 \mathrm{~cm}$ below, to the boundary (Racki et al. 2002); this agrees with the presence of several intervals with Trichichnus alternating with unbioturbated, non-laminated or occasionally laminated limestone beds. In the Płucki section, $\mathrm{V} / \mathrm{Cr}$ values are similar to oxic levels below the F-F without marked fluctuations (Racki et al. 2002). This could be correlated with the general dominance of bioturbated beds (Trichichnus and undetermined bioturbational structures) separated by a few thinner, unbioturbated intervals, which suggest the existence of minor fluctuations in oxygenation;

2. at the F-F boundary, important changes in $\mathrm{V} / \mathrm{Cr}$ values are recognized in both sections revealing impoverishment in oxygen conditions (Racki et al. 2002). They are especially marked in the Płucki section with values favouring the interpretation of anoxia (Bond et al. 2004), while the Kowala section represents fluctuations between oxic and dysoxic (Racki et al. 2002) or anoxic conditions (Joachimski et al. 2001). This pattern agrees with the general absence of trace fossils in both sections, around the F-F boundary at Kowala and in coincidence with this boundary at Płucki. Moreover, $\delta^{34} \mathrm{~S}$ and $\delta^{13} \mathrm{C}$ clearly point to anoxia on the sea floor as a result of an increase in organic carbon deposition and reduction of sulphur (Buggisch 1991);
3. above the Upper Kellwasser level, $\mathrm{V} / \mathrm{Cr}$ values reveal a relatively rapid improvement of oxic conditions in the Kowala section, and a prolonged deterioration in oxygenation maintained in the Plucki section (suboxic-anoxic; Racki et al. 2002). These improvements in oxic conditions correspond well to the appearance of Multina or ?Planolites some centimetres above the F-F boundary in the Kowala section. However, the dominance of unbioturbated beds, with only local appearance of Trichichnus, a possible single specimen of ?Curvolithus or undetermined bioturbational structures in the Płucki section still suggests prevailing anoxic conditions, as was also interpreted for the water column based on the previous geochemical studies (Joachimski et al. 2001).

Thus, ichnological data confirm the fluctuations on the sea floor oxygenation and their influence on the macrobenthic tracemaker community during the Upper Kellwasser event. Fluctuations in oxygenation before the F-F boundary and during the Upper Kellwasser event were possible. This is suggested by the presence of unbioturbated horizons between bioturbated beds. However, a bed of bituminous, cephalopod limestone in the Płucki area, interpreted as the Lower Kellwasser, has been recognized ca. $60 \mathrm{~m}$ below (Racki et al. 2002; Szrek and Ginter 2007) the Upper Kellwasser. Similarly, beds with TOC maximum in the Kowala section, corresponding to the Lower Kellwasser event, are recognized about $15 \mathrm{~m}$ below the F-F boundary (Joachimski et al. 2001; De Vleeschouwer et al. 2013). Our interpretation of oxygenation changes close to F-F boundary corresponds rather to the early Upper Kellwasser event. However, the absence of a high-resolution biostratigraphy precludes a more precise interpretation. Together with the generally oxygen-deficient lower water column during late Frasnian and early Famennian, TOC analysis in the Kowala section shows two maxima across the Frasnian-Famennian boundary transition correlated with the Lower and Upper Kellwasser events (Joachimski et al. 2001). These enhanced TOC concentrations were explained by a higher primary productivity (higher photoautotroph production) that could be associated with a higher supply of continentderived nutrients (Joachimski et al. 2001; Filipiak 2002; Kazmierczak et al. 2012). However, Riquier et al. (2006) proposed two different mechanisms responsible for oxygen deficiency during sedimentation of the Lower and Upper Kellwasser: the first one can be a result of an increase in productivity in shallow-water environments, while the second is caused by a development of eutrophic conditions in the basin.

Variations in productivity could be also envisaged based on the obtained ichnological data. Low-oxygenated bottom water and pore water combined with organic-rich sediments 
probably induce potentially ideal conditions for chemosymbiotic activity, favouring the presence of Trichichnus tracemaker (e.g. Löwemark et al. 2006). According to previous papers (e.g. Racki et al. 2002; Pujol et al. 2006; Winter 2015), organic matter production as well as oxygenation was controlled by tectono-magmatic processes (volcanism, hydrothermal phenomena) in enrichment in metals and nutrients and the lowering of the oxygenation during deposition of the Kellwasser horizons.

\section{Trace fossils and the Upper Kellwasser event worldwide}

Previous ichnological analyses focusing on the FrasnianFamennian transition are comparatively scarce (Stachacz and Uchman 2012; Haddad et al. 2013; Boyer et al. 2014). Boyer et al. (2014), based on a detailed ichnological and geochemical analysis in the western New York State (USA) interpreted long-term environmental perturbations, rather than a geologically instantaneous onset of anoxia as the causal mechanism of the extinction during the Upper Kellwasser event. Ichnological data support a rapid deoxygenation event below the horizon traditionally interpreted as the Upper Kellwasser anoxic interval, in the so-called precursor black shale bed (PBSB), then an increase in oxygen levels (not fully oxygenated), characterized by a shallow Chondrites-dominated assemblage, followed by a gradual decrease in the oxygen levels into the Upper Kellwasser black shale interval. These conditions are maintained for a relatively long period of persistent oxygen stress (but not persistent anoxia, as reflected by the presence of smaller tracemakers but excluding larger burrowing organisms) through this interval, and then rapidly shift to oxygenated environment above the Upper Kellwasser interval, as revealed by the appearance of the large Thalassinoides (Boyer et al. 2014).

Comparing the studied sections form Central Poland and these from New York State, in both cases, scarce and low-diversity trace fossil assemblages are present in the Frasnian-Famennian transition interval, which are dominated by small burrows, including Chondrites in the New York State, and Trichichnus in Poland; in both cases reflecting lowered oxygen conditions. Prior to the F-F transition interval (the Upper Kellwasser event), the PBSB recognized in New York State could be correlated with the record of unbioturbated, laminated or black, bituminous cephalopod limestone beds in Central Poland. Larger structures, such as Thalassinoides or Planolites/?Chondrites, reveal a return to better oxygenated conditions after the Upper Kellwasser event. In New York State, neither a rapid deoxygenation at the Upper Kellwasser event nor a persistent anoxia is interpreted, but a gradual decrease in oxygenation to dysoxic/suboxic levels. This pattern is similar to that occurring in the Kowala section, with low-oxygen conditions prior to the Upper Kellwasser event, then maintenance of dysoxia, followed by the improvement in bottom water oxygen conditions in a comparatively short time after the event.

In short, this comparison confirms the generalized incidence of fluctuating oxygen conditions associated with the Upper Kellwasser event, affecting the macrobenthic tracemaker community in a global scale. However, it is necessary to emphasize that the macrobenthic tracemaker community shows not a unique pattern, but a variable response, prior, during and after the event. In the case study from Poland, the presence of non-bioturbated, laminated intervals, allowing interpretation of anoxic conditions is a significant feature. This minor difference in comparison with New York State could be associated with local signals, caused, for instance, by variable topography and/or ocean dynamics, which may control duration and intensity of the oxygen deficiency. It might be worth noting that while there are predictable differences in the signals, overall they are quite similar, which speaks to a global scale driver rather than something local. This seems an important point to pull out of these comparisons.

\section{Conclusions}

1. The laminated, non-bioturbated beds of marlstones or shales, usually with pyrite above Frasnian-Famennian boundary, indicate anoxia on the sea floor just after the F-F event. However, the anoxic event occurs earlier than the F-F, as recorded by a bed of laminated limestone.

2. The increase in abundance of trace fossils and bioturbational structures in some beds above the F-F boundary is interpreted as an increase in bottom water oxygen levels.

3. Low ichnodiversity suggests an unfavourable environment for the most burrowing organisms. In this general context, the presence of laminated intervals, horizons with opportunistic Trichichnus, and only spotty and mottled ichnofabrics, with the larger trace fossils Multina or ?Planolites, allows the interpretation of fluctuations in oxygenation from anoxic, strongly dysoxic and dysoxic conditions.

Acknowledgments Research by M. S. and A. U. was supported by Jagiellonian University (Project DS/MND/WBiNoZ/ING/2/2011 and DS funds, respectively). M. S. wishes to thank to Dyckerhof Polska Company (Sitkówka-Nowiny) for the field work permission in the Kowala quarry. Financial support by R.-T. was provided by the Project CGL2012-33281 (Secretaría de Estado de I+D+I, España) and the research group RNM-178 (Junta de Andalucía). G. Racki (University of Silesia), D. Boyer (Shineman Science Center) and an anonymous reviewer provided constructive reviews. 
Open Access This article is distributed under the terms of the Creative Commons Attribution 4.0 International License (http://creativecommons.org/licenses/by/4.0/), which permits unrestricted use, distribution, and reproduction in any medium, provided you give appropriate credit to the original author(s) and the source, provide a link to the Creative Commons license, and indicate if changes were made.

\section{References}

Becker RT, Gradstein FM, Hammer O (2012) The Devonian period. In: Gradstein FM, Ogg JG, Schmitz M, Ogg G (eds) The geologic time scale 2012. Elsevier, Amsterdam, pp 559-601

Bond DPG, Wignall PB (2008) The role of sea-level change and marine anoxia in the Frasnian-Famennian (Late Devonian) mass extinction. Palaeogeogr Palaeoclimatol Palaeoecol 263:107-118

Bond DPG, Wignall PB, Racki G (2004) Extent and duration of marine anoxia during the Frasnian-Famennian (Late Devonian) mass extinction in Poland, Germany, Austria and France. Geol Mag 141:173-193

Borcuch E, Rakociński M (2007) Mikroorganizmy z dolnego famenu kowali (Góry Świętokrzyskie)—implikacje paleośrodowiskowe. In: Żylińska A (ed) Granice Paleontologii, XX Konferencja Naukowa Paleobiologów i Biostratygrafów PTG, Św. Katarzyna pod Łysicą, 10-13 września 2007 r., Materiały konferencyjne, 38-39 (in Polish)

Boyer DL, Haddad EE, Seeger ES (2014) The last gasp: trace fossils track deoxygenation leading into the Frasnian-Famennian extinction event. Palaios 29:646-651

Buggisch W (1991) The global Frasnian-Famennian Kellwasser event. Geol Runschau 80:49-72

Buła Z (2000) The lower palaeozoic of upper Silesia and West Małopolska. Prace Państwowego Instytutu Geologicznego 171: 1-63 (in Polish, English abstract)

Cocks LRM, Torsvik TH (2005) Baltica from late Precambrian to mid-Palaeozoic times: The gain and loss of terrane's identity. Earth Sci Rev 72:39-66

Copper P (2002) Reef development at the Frasnian/Famennian mass extinction boundary. Palaeogeogr Palaeoclimatol Palaeoecol 181:27-65

De Vleeschouwer D, Rakociński M, Racki G, Bond DPG, Sobień K, Claeys P (2013) The astronomical rhythm of Late-Devonian climate change (Kowala section, Holy Cross Mountains, Poland). Earth Planet Sci Lett 365:25-37

Filipiak P (2002) Palynofacies around the Frasnian/Famennian boundary in the Holy Cross Mountains, southern Poland. Palaeogeogr Palaeoclimatol Palaeoecol 181:314-324

Gereke M, Schindler E (2012) "Time-Specific Facies" and biological crises-The Kellwasser Event interval near the Frasnian/Famennian boundary (Late Devonian). Palaeogeogr Palaeoclimatol Palaeoecol 367-368:19-29

Girard C, Lécuyer C (2002) Variations in Ce anomalies of conodonts through the Frasnian-Famennian of Poland (Kowala-Holy Cross Mountains): implications for the redox state of seawater and biodiversity. Palaeogeogr Palaeoclimatol Palaeoecol 181:299-311

Haddad E, Boyer DL, Love GD, Droser ML (2013) Application of trace fossils, trace metals, and lipid biomarkers toward an understanding of Upper Kellwasser shale deposition, New York State. Geol Soc Am Abstr Prog 45:754

Hallam A, Wignall PB (1997) Mass extinctions and their aftermath. Oxford University Press, Oxford

Hallam A, Wignall PB (1999) Mass extinctions and sea-level changes. Earth Sci Rev 48:217-250
Janiszewska K, Szrek P, Woroncowa-Marcinowska T (2007) Zapis zdarzeń biotycznych na pograniczu frańsko-fameńskim w Płuckach koło Łagowa. In: Żylińska A (ed) Granice Paleontologii, XX Konferencja Naukowa Paleobiologów i Biostratygrafów PTG, Św. Katarzyna pod Łysicą, 10-13 września 2007 r., Materiały konferencyjne, 63-66 (in Polish)

Joachimski MM, Buggisch W (2007) Conodont apatite $\delta^{18} \mathrm{O}$ signatures indicate climatic cooling as a trigger of the Late Devonian mass extinction. Geology 30:711-714

Joachimski MM, Ostertag-Henning C, Pancost RD, Strauss H, Freeman KH, Littke R, Sinninghe Damste JS, Racki G (2001) Water column anoxia, enhanced productivity and concomitant changes in $\delta^{13} \mathrm{C}$ and $\delta^{3} 4 \mathrm{~S}$ across the Frasnian-Famennian boundary (Kowala-Holy Cross Mountains/Poland). Chem Geol 175:109-131

Joachimski MM, Breisig S, Buggisch W, Talent JA, Mawson R, Gereke M, Morrow JR, Day J, Weddige K (2009) Devonian climate and reef evolution: insights from oxygen isotopes in apatite. Earth Planet Sci Lett 284:599-609

Kaźmierczak J, Kremer B, Racki G (2012) Late Devonian marine anoxia challenged by benthic cyanobacterial mats. Geobiology 10:371-383

Kędzierski M, Uchman A, Sawłowicz Z, Briguglio A (2015) Fossilized bioelectric wire-the trace fossil Trichichnus. Biogeosciences 12:2301-2309

Kotlarczyk J, Uchman A (2012) Integrated ichnology and ichthyology of the Oligocene Menilite Formation, Skole and Subsilesian nappes, Polish Carpathians: a proxy to oxygenation history. Palaeogeogr Palaeoclimatol Palaeoecol 331-332:104-118

Löwemark L, Lin Y, Chen HF, Yang TN, Beier C, Werner F, Lee CY, Song SR, Kao SJ (2006) Sapropel burn-down and ichnological response to late Quaternary sapropel formation in two $\sim 400 \mathrm{ky}$ records from the eastern Mediterranean Sea. Palaeogeogr Palaeoclimatol Palaeoecol 239:406-425

Marynowski L, Rakociński M, Borcuch E, Kremer B, Schubert AB, Jahren AH (2011) Molecular and petrographic indicators of redox conditions and bacterial communities after the F/F mass extinction (Kowala, Holy Cross Mountains, Poland). Palaeogeogr Palaeoclimatol Palaeoecol 306:1-14

McBride EF, Picard DM (1991) Facies implications of Trichichnus and Chondrites in turbidites and hemipelagites, Marnoso-arenacea Formation (Miocene), Northern Apennines, Italy. Palaios 6:281-290

McGhee GR (2013) When the invasion of land failed: the legacy of the Devonian extinctions. Columbia University Press, New York

Monaco P, Rodríguez-Tovar FJ, Uchman A (2012) Ichnological analysis of lateral environmental heterogeneity within the Bonarelli Level (uppermost Cenomanian) in the classical localities near Gubbio, Central Apennines, Italy. Palaios 27:48-54

Narkiewicz M (1988) Turning points in sedimentary development in the Late Devonian in southern Poland. In: McMillan NJ, Embry AF, Glass DJ (eds) Devonian of the world, vol 14. Canadian Society of Petroleum Geologists, Memoir, pp 619-635

Narkiewicz M, Racki G, Wrzołek T (1990) Litostratygrafia dewońskiej serii stromatoporoidowo-koralowcowej w Górach Świętokrzyskich. Kwart Geol 34:433-456

Olempska E (2002) The Late Devonian Upper Kellwasser Event and entomozoacean ostracods in the Holy Cross Mountains, Poland. Acta Palaeontol Pol 47:247-266

Pujol F, Berner Z, Stüben D (2006) Palaeoenvironmental changes at the Frasnian/Famennian boundary in key European sections: Chemostratigraphic constraints. Palaeogeogr Palaeoclimatol Palaeoecol 240:120-145

Racki G (1990) Frasnian/Famennian event in the Holy Cross Mts, Central Poland: stratigraphic and ecologic aspects. In: Kaufman 
EG, Walliser O (eds) Extinction events in earth history. Lecture notes in earth sciences, vol 30. Springer, Berlin, pp 169-181

Racki G (2005) Toward understanding Late Devonian global events: few answers, many questions. In: Over DJ, Morrow JR, Wignall PB (eds) Understanding Late Devonian and Permian-Triassic biotic and climatic events: towards an integrated approach, chapter 2. Elsevier, Amsterdam, pp 5-36

Racki G, Baliński A (1998) Late Frasnian Atrypida (Brachiopoda) from Poland and the Frasnian-Famennian biota crisis. Acta Palaeontol Pol 43:273-304

Racki G, Racka M, Matyja H, De Vleeschouwer D (2002) The Frasnian/Famennian boundary interval in the South PolishMoravian shelf basins: integrated event-stratigraphical approach. Palaeogeogr Palaeoclimatol Palaeoecol 181:251-297

Reolid M, Mattioli E, Nieto LM, Rodríguez-Tovar FJ (2014) The early Toarcian anoxic event in the External Subbetic (Southiberian Palaeomargin, Westernmost Tethys): geochemistry, nannofossils and ichnology. Palaeogeogr Palaeoclimatol Palaeoecol 411:79-94

Riquier L, Tribovillard N, Averbuch O, Devleeschouwer X, Riboulleau A (2006) The Late Frasnian Kellwasser horizons of the Harz Mountains (Germany): Two oxygen-deficient periods resulting from different mechanisms. Chem Geol 233:137-155

Rodríguez-Tovar FJ, Reolid M (2013) Environmental conditions during the Toarcian Oceanic Anoxic Event (T-OEA) in the westernmost Tethys: influence of the regional context on a global phenomenon. Bull Geosci 88:697-712

Rodríguez-Tovar FJ, Uchman A (2010) Ichnofabric evidence for the lack of bottom anoxia during the lower Toarcian Oceanic Anoxic Event in the Fuente de la Vidriera section, Betic Cordillera, Spain. Palaios 25:576-587

Rodríguez-Tovar FJ, Uchman A, Martín-Algarra A (2009a) Oceanic anoxic event at the Cenomanian-Turonian boundary interval (OAE-2): ichnological approach from the Betic Cordillera, southern Spain. Lethaia 42:407-417

Rodríguez-Tovar FJ, Uchman A, Martín-Algarra A, O’Dogherty L (2009b) Nutrient spatial variation during intrabasinal upwelling at the Cenomanian-Turonian oceanic anoxic event in the westernmost Tethys: an ichnological and facies approach. Sed Geol 215:83-93

Stachacz M, Uchman A (2012) Ichnological Record of the FrasnianFamennian Boundary interval in the Kowala Quarry (Holy Cross
Mountains, Poland), Abstract Book, Ichnia 2012, The 3rd International Congress on Ichnology, 9-24 August, 2012, Memorial University of Newfoundland, St. John's, Canada, p 81

Stigall AL (2012) Speciation collapse and invasive species dynamics during the Late Devonian "mass extinction". GSA Today 22:4-9

Szrek P, Ginter M (2007) Poziomy wapieni typu Kellwasserkalk w Płuckach koło Łagowa. In: Żylińska A (ed), Granice Paleontologii, XX Konferencja Naukowa Paleobiologów iBiostratygrafów PTG, Św. Katarzyna pod Łysicą, 10-13 września 2007 r., Materiały konferencyjne, pp 157-161

Uchman A (1995) Taxonomy and palaeoecology of flysch trace fossils: the Marnoso-arenacea Formation and associated facies (Miocene, Northern Apennines, Italy). Beringeria 15:1-116

Uchman A, Bạk A, Rodríguez-Tovar FJ (2008) Ichnological record of deep-sea palaeoenvironmental changes around the Oceanic Anoxic Event 2 (Cenomanian-Turonian boundary): an example from the Barnasiówka section, Polish Outer Carpathians. Palaeogeogr Palaeoclimatol Palaeoecol 262:61-71

Uchman A, Rodríguez-Tovar FJ, Machaniec E, Kędzierski M (2013a) Ichnological characteristics of Late Cretaceous hemipelagic and pelagic sediments in a submarine high around the OAE- 2 event: a case from the Rybie section, Polish Carpathians. Palaeogeogr Palaeoclimatol Palaeoecol 370:222-231

Uchman A, Rodríguez-Tovar FJ, Oszczypko N (2013b) Exceptionally favourable life conditions for macrobenthos during the Late Cenomanian OAE-2 event: ichnological record from the Bonarelli Level in the Grajcarek Unit, Polish Carpathians. Cretac Res 46:1-10

Vishnevskaya V, Pisera A, Racki G (2002) Siliceous biota (radiolarians and sponges) and the Late Devonian biotic crisis: the Polish reference. Acta Palaeontol Pol 47:21-226

Wang Y, Wang X, Shi X (2006) Pioneer organisms after F-F mass extinction in Dushan region, Guizhou Province, and their significance in establishing new ecosystem. Sci China Ser D Earth Sci 49:449-460

Winter J (2015) Vulkanismus und Kellwasser-Krise-ZirkonTephrostratigrafie, Identifizierung und Herkunft distaler Fallout-Aschenlagen (Oberdevon, Synklinorium von Dinant, Rheinisches Schiefergebirge, Harz). Zeitschrift der Deutschen Gesselschaft für Geowissenschaften 166:227-251 